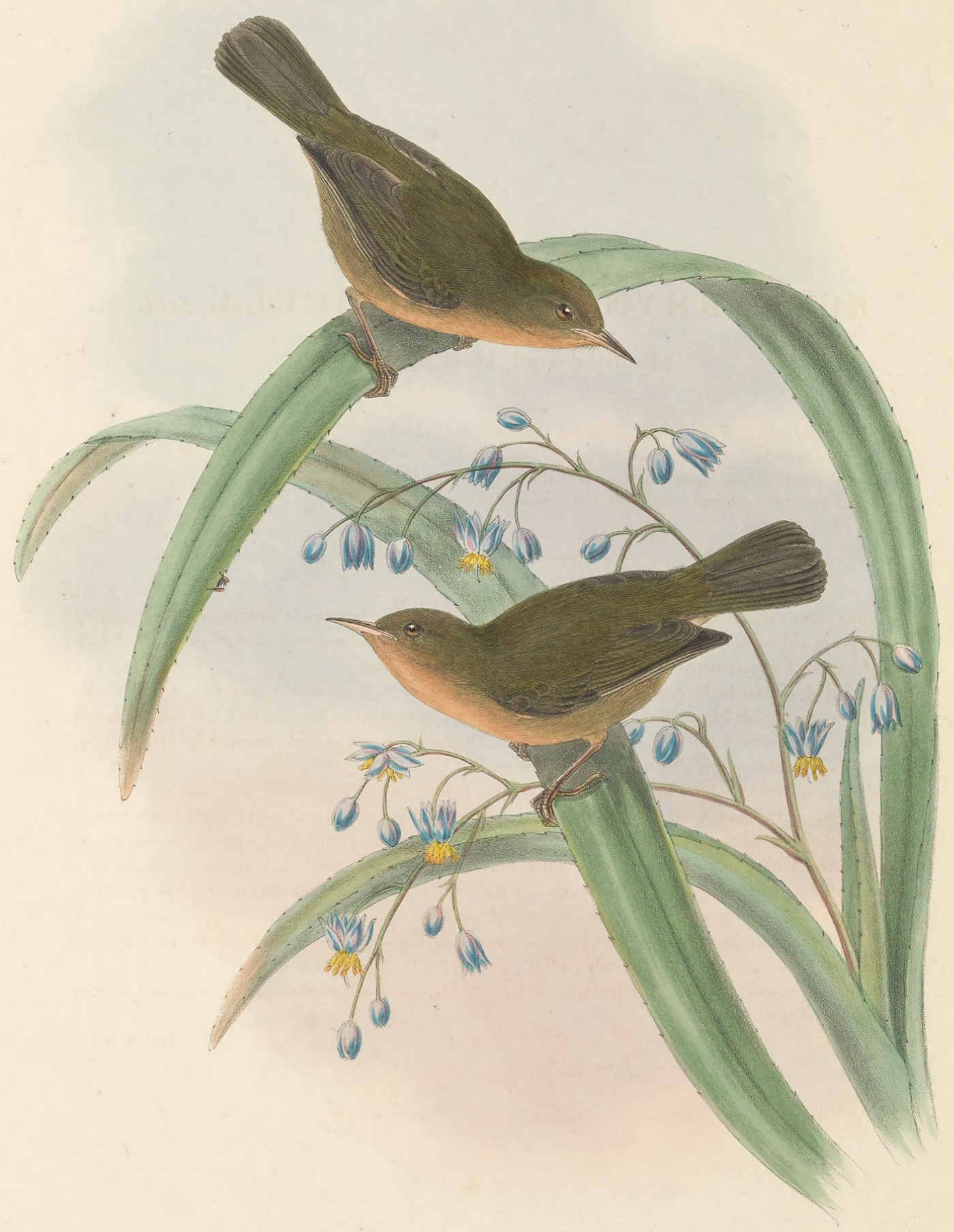




\section{EUTHYRHYNCHUS FULVIGULA,schl.}

\section{Buff-throated Honey-eater.}

Euthyrhynchus fulvigula, Schl. Nederl. Tijdschr. Dierk. iv. p. 40 (1871).-Salvad. Ann. Mus. Civic. Genov. xii. p. 343 (1875).-Rosenb. Malay. Arch. pp. 553, 586 (1879).-Salvad. op. cit. xvi. p. 78 (1880).-Id. Orn. Papuasia e delle Molucche, ii. p. 342 (1881).

Timeliopsis acutirostris, Salvad. Ann. Mus. Civic. Genov. vii. p. 964 (1875).

THIs is the most distinct of all the species of the genus Euthyrhynchus, and is distinguished not only by the olive-green colour of the upper surface, but also by the amount of olive-green on the lower parts, which causes the tawny buff colour of the throat to appear in strong contrast.

It was first described by Professor Schlegel from a specimen in the Leyden Museum, and has since been discovered in the Arfak Mountains by Mr. Bruijn's hunters, as well as by Dr. Beccari. Count Salvadori remarks on the affinity of this genus to the Australian Plectorhyncha, a fact also observed by Mr. Ramsay, who named one of the species Plectorhyncha fulviventris.

Adult. General colour above dull olive-green, a little lighter on the lower back and rump; lesser and median wing-coverts, greater coverts, bastard-wing, and primary-coverts as well as the quills dusky brown, edged with olive-green like the back, a little more yellow on the primaries; tail-feathers dusky brown, edged with olive-green; head like the back, but a little more dingy and inclining to dull ashy olive; lores ashy fulvous; eyelid and ear-coverts dull ashy, as well as the feathers below the eye ; throat light tawny ; breast pale pinkish brown, slightly washed with olive-yellow ; sides of body and under tail-coverts pale olive-greenish as well as the thighs; axillaries and under wing-coverts pale fawn-buff; quills dusky below, whitish along the inner web. Total length 5 inches, culmen 0.65 , wing $2 \cdot 65$, tail $2 \cdot 05$, tarsus $0 \cdot 8$.

The above description is that of a specimen which the Marquis Doria lent to us; it is figured in two positions, and of the natural size. 


\section{$2 \mathrm{BHL}$ Biodiversity Heritage Library}

Gould, John and Sharpe, Richard Bowdler. 1885. "Euthyrhynchus fulvigula, Buff-throated Honey-eater [PI. 54]." The birds of New Guinea and the adjacent Papuan islands : including many new species recently discovered in Australia 3(XX), -. https://doi.org/10.5962/p.322767.

View This Item Online: https://www.biodiversitylibrary.org/item/229963

DOI: https://doi.org/10.5962/p.322767

Permalink: https://www.biodiversitylibrary.org/partpdf/322767

\section{Holding Institution}

Smithsonian Libraries

\section{Sponsored by}

Biodiversity Heritage Library

\section{Copyright \& Reuse}

Copyright Status: Public domain. The BHL considers that this work is no longer under copyright protection.

This document was created from content at the Biodiversity Heritage Library, the world's largest open access digital library for biodiversity literature and archives. Visit BHL at https://www.biodiversitylibrary.org. 